\title{
Selected Problems of Family Business: A Case Study from Slovakia
}

\author{
Tomáš Peráček ${ }^{1, *}$, Lucia Vilčeková ${ }^{2}$ and Lubomíra Strážovská ${ }^{2}$ \\ ${ }^{1}$ Department of Informations Systems, Faculty of Management, Comenius \\ University in Bratislava, Odbojárov 10, 82005 Bratislava, Slovak Republic; \\ tomas.peracek@fm.uniba.sk \\ ${ }^{2}$ Department of Marketing, Faculty of Management, Comenius University in \\ Bratislava, Odbojárov 10, 82005 Bratislava, Slovak Republic; \\ lucia.vilcekova@fm.uniba.sk; lubomira.strazovska@fm.uniba.sk \\ *Corresponding author
}

\begin{abstract}
The scientific paper deals with a part of the business sector, which is made up of family businesses. The paper presents the current status of such businesses from the perspective of positive and negative factors which will be linked to the problem areas. In this article, we have focused our attention on some aspects of family business, especially the managerial aspects, because the management of a family business has various differences and specifics compared to other types of businesses. In the theoretical part, we present the current state of the issue, while the empirical part of the article is based on a survey conducted among family businesses using a questionnaire. This article does not aim to highlight the contentious areas of family business. However, it brings valuable findings of business practice. More than 400 enterprises were approached, the resulting sample consisted of 185 family enterprises. Therefore, we understand the results as a case study from Slovakia. Our findings were subject to statistical analysis using several quantitative methods (t-test, regression models) and we present them in the empirical part. Based on our results, we bring the most valuable findings and ideas for further research.
\end{abstract}

Keywords: family business; business problems; $t$-test; regression model

\section{Introduction}

The importance of doing business in every market economy lies mainly in the development of the economy and job creation. The term business environment is a term known and often used, yet its definition is neither simple nor unambiguous, especially given the large number of entities involved in its design. The business environment reflects the quality of economic conditions and the basis for the economic activity of entrepreneurs [6]. The business environment of the Slovak 
Republic has been examined by researchers since the political change in 1989 when the economy underwent a change from centrally planned to a market economy. For decades, the declared effort of the Government of the Slovak Republic has been to create a favorable business environment. This is essential not only for large investors but also for small and medium-sized enterprises, which are often operated as family businesses in Slovak conditions. This particular category of businesses represents the most powerful engine of the economy in the developed countries, especially in Western Europe, as they represent a number of advantages.

In essence, family and family businesses are two intertwining and interacting worlds. But there are values and principles that make up the family and shape the business. The entrepreneur's family life, personality, and interests are often the main driving force in doing business. However, an entrepreneur has to deal with a situation where his or her business threatens the family, but also with a situation where his/her own family threatens the business and thus the economic existence.

Small and middle-sized enterprises are most vulnerable to changes in the business environment, they have limited access to trades where large investments are required, they may be threatened by multinational or large enterprises, they cannot afford to employ top scientists, managers, professionals. Last but not least, they are unable to monitor available resources.

As Mura states, in recent years, several economic and political instruments have been adopted to support small and middle-sized business [24]. However, we see the problem is the fact that none of them focused exclusively on family businesses. Unlike the Slovak Republic, the European Union has adopted a number of measures aimed at increasing the competitiveness of small and medium-sized enterprises, but also of family businesses. The above-mentioned legislative measures are also adopted in connection with the administration of the family business. According to these, EU legislation measures, up to $85 \%$ of all businesses can be considered as family-owned, and these businesses employ up to $60 \%$ of all employees.

The business process, as well as family business, are much more developed in western countries, which has been caused in particular by the favorable political situation, but also by centuries of evolving the business processes. Therefore, western countries are an inspiration for our young entrepreneurs.

The past three decades in Slovakia were shaped by the emergence and subsequent development of small and medium-sized enterprises [17, 18]. The merits of the representation of these business units in the country's economy were confirmed. In the transition to a market economy, it was once again small and middle-sized enterprises that helped significantly transform the economy and laid the foundation for the functioning of smaller businesses. As part of the transformation of the economy, families have returned to their previously confiscated property 
and have taken ownership of various businesses. Therefore, in Slovakia the family business had to develop again from the beginning.

Family businesses represent the oldest form of business not only in Europe but also in our country. The reason that they are the object of our research is that they are long-term established companies that create jobs even in less developed regions without the interest of foreign investors and have a great perspective especially for small and medium-sized enterprises [30]. Their main advantage is usually less risk and greater stability due to conservative management and longterm sustainability. Family businesses in Slovakia have been facing problems for a long time; most often it is the changing legislation, a number of constraints, lack of skilled labor, low law enforcement, lack of advice, and assistance from public authorities [22].

During the survey, we found out what problems family businesses in Slovakia are facing at present. The main aim of the paper is to investigate the problems of Slovak family businesses. On the basis of the data obtained, we will propose options to eliminate the most serious problems that family businesses have been facing in our conditions for a long time.

\section{Theoretical Background}

Entrepreneurship itself can be characterized as a source of dynamic movement in the economy, and at the same time it forms the basis of a market economy, which is a living active organism. Without entrepreneurship, a market-oriented economy could not exist because it constitutes its absolute basis on which other economic operators and the national economy sector are linked. That is why business support should be at the center of interest not only for economists but, above all, for politicians, to create an appropriate and favorable environment for the development of entrepreneurial activities.

The priority role of each country's economy is to support the development of small and medium-sized enterprises, of which family businesses are also a part. Creating a suitable business environment, which means simplifying and clarifying the relevant legislation, reducing administrative, levy, and tax burdens, strengthening support infrastructure, and improving access to capital are the most important factors for its development. In the European Union, the share of SMEs is $99.8 \%$, and approximately $2 / 3$ of all employees are employed in this sector. Small and medium-sized enterprises are generally considered to carry a substantial part of the innovation impulses, and are also very flexible in the changing market environment and constitute an important segment for regional economic growth, writes Kachanek, Stalk, Bloch [19]. 
In particular, national governments should support, through appropriate instruments, the creation of new and retaining existing business units and support their continuous development conditional on further education, a favorable business environment, and available expert advice and tutoring. Support for local SMEs has undeniable advantages for all interested groups and the effort will undoubtedly pay off.

The drivers of a market economy in the $21^{\text {st }}$ Century are businesses, mostly private-owned SMEs and family businesses. They are an indispensable pillar of the economy of each prosperous state and play an important role in the process of developing national economies. Their importance is also evident in the creation of the gross domestic product, on the one hand, and on the other, they have an important position in employment issues not only within the European Union but also on a global scale.

In Slovakia, the sector of small, medium-sized, and family businesses make up more than half of the business units, based on the findings of Kvašnák and Makarovičová [21]. This was the primary reason for which the government decided to start to support family businesses. These types of businesses help to reduce the unemployment rate in many regions suffering from disparities and the disinterest of larger business units.

In this context, there is a fundamental problem in Slovakia of how to approach the definition of a family business. It is not easy to define a family business because the Slovak legislature does not know this term, but in general, it is possible to speak of a family business if the business owner is a family member, the business is managed by a family member or the next generation of the founder Practice shows that in many cases family businesses are created as small and mediumsized enterprises.

There is no legal definition of the term 'family business' or 'family enterprise' in the Slovak legal order. Therefore, as stated by Mucha we can only rely on general legal definitions of the terms business, enterprise, and family [26]. The term 'company' does not have a uniform definition. The Commercial Code describes a company as a set of tangible as well as personal and intangible components of doing business.

Experts in the field such as, e.g. (Dudic et al.) say the definition of family businesses is based on different criteria than legal science [12]. According to them, first of all, small and family-run businesses have a relatively small market share and cannot influence the market significantly. According to Belas et al. the second feature is that they are managed by the owners (entrepreneurs), the families of the owners, not mediated through the formal management structure $[8$, 9]. The third feature is their independence as they do not form part of a larger enterprise. 
To compare the differences in the definition, Zufan et al. lists several features of a family business that are applied in the US [39]. Primarily, the family has a major influence on the management and development of the business and its strategic goal is to pass the business on to the next generation. It is important that the family business is owned by the founder and his descendants. Anyakoha adds that the family business is a business of several generations [4]. This means in American practice that the family manages the business directly, the assets of the business are owned by the family and more than one member of the family is in business management.

Serina, however, points to the definition of the Massachusetts Mutual Life Company, which defines a family business by alternatively fulfilling at least one of three characters [31]. The owner considers his business to be a family business or intends to hand it over to a close relative or, in addition to it, another member of the family who is part of the day-to-day management process of the business works as a full-time employee.

However, in this context, we consider it necessary to properly include the concept of a family business in the legal order. We appreciate the legislator's intention to deal with such sensitive issues as the share of profits from the family business as well as other property rights from the operation of the family business, which creates additional property rights of the participating family members. However, Śtafy negatively assesses that these are disposable provisions of the Act which also allow for a different agreement between the participants [34].

\subsection{The Nature of Family Business and Its Problems}

The specificity of family business lies in the interaction of the family and the business environment. The founder of a family business is usually also a statutory body. We consider this to be the main reason why there is often an undesirable interaction between the harsh business climate and sensitive family ties. It is difficult to distinguish and separate relationships that are professional and emotional. The result of this clash is the need for an entrepreneur to address the issue of priorities between business and personal life. According to Zygmunt, however, every family has a natural endeavor to survive, especially if it is existentially dependent on the results of the business activities [38]. This, in comparison with "foreign employees", motivates the family members to make generally greater efforts to achieve a successful outcome. Ślusarczyk and Haque point out that there should also be greater mutual trust among family members [33]. This assumption leads him to conclude that, for this reason, family businesses have longer-term stability and will survive several generations. The focus of family business is often the so-called family interest, which is created by involving multiple family members in the business. Such a strong family unit is, after all, a better prerequisite for the transfer of experience from generation to 
generation. The personal factor is not only a source of stability but also a tradition, which creates a strong basis for business continuity and its future prosperity [5].

One of the specifics of family businesses is, in particular, the flexibility to make decisions, giving priority to family members in managerial positions regardless of meeting the required criteria. Differences from other types of businesses, according to De Alvis can be also seen in aspects such as motivation, solidarity, and coherence [2]. These are related to the dependence of the family on the success of the business. According to Ključnikov et al. and Švec et al. is the key of success of every business, not just family business the exchange of information because we live in the information era [20,35]. This information exchange is sincere and direct among family members, and moreover, without any speculation. Another important advantage of a family business is, according to Rahman et al. cost optimization [28]. It should be understood that family members are easier to agree on setting up substantial cost items, e.g. own wages.

In view of the fact that family businesses in the Slovak Republic are part of the category of small and middle-sized enterprises, their advantages also lie in the advantages that are characteristic of small and middle-sized enterprises. Among the most important, Nagy et al. incorporates a simple management structure, the possibility of increasing employment, innovation [27]. Meszároš and Divékyová add benefits like the ability to create self-employment, better knowledge of customer needs and the ability to address specific problems, but especially the use of regional labor, regional resources, contributing to reducing regional disparities [23].

Many family businesses use their own abilities and skills, making them more flexible to make decisions and responding more quickly to changes. From a broader perspective, they are, therefore, more stable. Their key advantage over large enterprises is their stability, as it is not their practice to move to other countries when state incentives are exhausted [36].

The change of the political system and transition to a market economy posed a serious problem for the older generation. Most employees, when they reach the age of 50, cannot find employment in the labor market if they lose their jobs because of employers' prejudices. From the point of view of several of the abovementioned authors, it is possible to see the advantage of a family business in favor of a social care and security because the family business is not age-limited.

Family business and the related overlapping of family and making business can result in uncontrollable problems. As reported by Dudic et al. and Bure and Tengeh the problems mainly occur where there is no sincerity and mutual trust among family members $[13,10]$. This results in the transfer of business conflicts to family life, and vice versa. These disputes may not only effect the business but may also result in its termination. That is why the literature recommends that the basic formal rules between individual family members should be defined before starting a business [32]. It is essential that the family is always able to name 
problems and solve them before they endanger the business. One possible solution, following the example of the Czech Civil Code, is to create a family council that would meet on a regular basis and solves problems before they cross the permissible limits.

Other problems in family businesses, according to Dul'ová et al. occur in the field of labor relations [14]. It is harder, sometimes impossible, to deduce the consequences for a breach of work discipline, failure to perform duties, or insufficient work performance towards family members compared to other employees. Our research has shown that only $15 \%$ of family businesses do not favor family members over other employees.

We also found out that up to $86 \%$ of family businesses do not address the issue of succession. Zajkovski and Domanska state that this is the most critical period of the existence of a family business [37]. Mura and Kaisar agree and state that there is also a breakthrough moment [25]. The founders usually try to delay this moment as much as possible in order to keep the business under control. The inability to leave the business and leave it to the successor is an insoluble problem for them. In the opinion of psychologists, there is a particularly inwardly suppressed fear of concern. International statistics show that only one-third of family businesses can handle generational exchange, with only a fraction of them remaining in the family's property for more than 50 years [29].

Haviernikova et al. are of the opinion that, in order to maintain business continuity, it is necessary to prepare for the transfer of succession well in advance and with the help of a psychologist [15]. In the absence of a suitable candidate, there are several possibilities. Selling a business is the easiest option. However, we consider ensuring a continuity of business management through a professional manager as a more suitable solution.

According to Ahmad et al. and Androniceanu et al. family businesses have several advantages, but also many problems [1,3]. Difficult access to foreign sources of financing, especially credit, is increasingly plaguing family businesses. Business education is also problematic. Both the professional community and entrepreneurs have been calling for more time and space to be devoted to this issue in the educational process. There is also a need to increase spending on research and development of innovative technologies, including control of spending efficiency. Research results also show that the administrative burden is the biggest problem in the family businesses. In addition, Belas et al. see the problems in a lack of access to information, as well as a constantly changing business environment and poor availability of relevant information [7].

Before starting a business in the form of a family business, we recommend considering a number of facts, in particular the issue of coping with crisis situations. The disadvantages of family businesses can sometimes not be eliminated, but by using prevention these can be eliminated [16]. However, the benefits of family business can include a better form of cooperation, greater 
credibility in the workplace as well as customer awareness, easier acquisition or expansion of capital, flexible working time, family cohesion especially in difficult times, as well as informal relationships in the workplace [11].

\section{Methodology}

The theoretical definition of the issue was defined in the first part of this article. We are currently dealing with methodological issues. The aim of the article is to point out the problem areas of family businesses and the problems that Slovak family businesses encounter. At the same time, as a partial goal, we sought to find out, with the help of statistical analyzes, deeper links to specific issues of family businesses. In addition to the theoretical research of literary sources, we conducted a survey among Slovak family businesses to process this article. More than 400 enterprises were approached, the resulting sample consisted of 185 family enterprises willing to participate in the survey and providing the necessary information.

The methodology is an important part of the research work. Depending on the topic, we carefully selected possible methodological options. We used one of the most common methods of quantitative research - a survey with questionnaire.

The survey is a method often used in qualitative research because it provides a source of primary data and feedback, which is one of the most important components of the system. The advantage of this method is the possibility of analysis using various statistical software. On the contrary, the disadvantage is often insufficient sample size, failure to meet some prerequisites, respectively, poor sampling, sometimes the problem is the credibility of the respondent's answers.

If we want to describe the correlation between two variables, it is appropriate to use the so-called correlation coefficient having the following form:

$r_{x y}=\frac{\overline{x y}-\bar{x} \cdot \bar{y}}{\sqrt{\left(\overline{x^{2}}-\bar{x}^{2}\right)}\left(\overline{y^{2}}-\bar{y}^{2}\right)}$

"The correlation coefficient shall take the interval value $\langle-1,1\rangle$. If the value is positive, $r_{x y}>0$, we indicate direct dependence, as the values of variable $x$ increase, the values of variable y tend to grow. If the values of the correlation coefficient are negative, $r_{x y}<0$, we indicate indirect dependence that is, when the values of the variable $x$ increase, the values of the variable $y$ tend to decrease. If $\mathrm{r}_{\mathrm{xy}}=0$, both variables are linearly independent. These variables are said to be uncorrelated." 
In our case, we will consider significant values of at least a slight correlation, i.e. greater than 0.3 and less than -0.3 in the case of indirect correlation. A strong correlation can be considered one when the coefficient values are higher than 0.5 or below -0.5 .

If we want to test statistical hypotheses, we need to use appropriate statistical methods, in this case we will perform nonparametric goodness o fit tests. Based on the nature of our research, we will use goodness of fit tests for variance and average.

Example of a statistical hypothesis:

$\mathrm{H}_{\mathrm{O}}$ (zero hypothesis): the averages of the two statistical sets are the same,

$\mathrm{H}_{1}$ (alternative hypothesis): the mean of the two statistical sets are not equal.

If the so-called p-value (determined by a statistical software) is less than the significance level $\alpha$, which in our case will be 0.05 , then the null hypothesis is rejected and the alternative hypothesis $\mathrm{H}_{1}$ cannot be rejected. If the $\mathrm{p}$-value is greater than the significance level, the null hypothesis cannot be rejected. The strength of statistical methods combined with reliable sampling is that the results are valid for the entire population.

In addition to the survey, hypothesis testing, elementary scientific methods (induction, deduction, analysis, synthesis), we also used t-test and regression models. These advanced methods have helped us identify a number of important facts.

\section{Results and Discusion}

The sample consisted of 185 family businesses willing to participate in the research. However, more than 400 family businesses were addressed. Indirect export (46 enterprises) was identified as the most used method of internationalization of entrepreneurial activity by family enterprises that participated in the research. The second most frequent way to enter international environment is a subsidiary abroad (33 companies). The research included family businesses, according to a well-defined definition of family business. These were the enterprises that the owner considered a family business or employed members of his family. The questionnaires were sent to companies and the questionnaire completion was dependent on the voluntary participation of employees in the research.

In descriptive statistics, we would like to give a description of the age structure of the sample. Based on the results of the variable age analysis presented below, it can be seen that the sample examined is skewed to the left, which means the most 
of the values are centered to the right of the average. Thus, on the basis of these results, we conclude that the number of older respondents prevails in the sample.

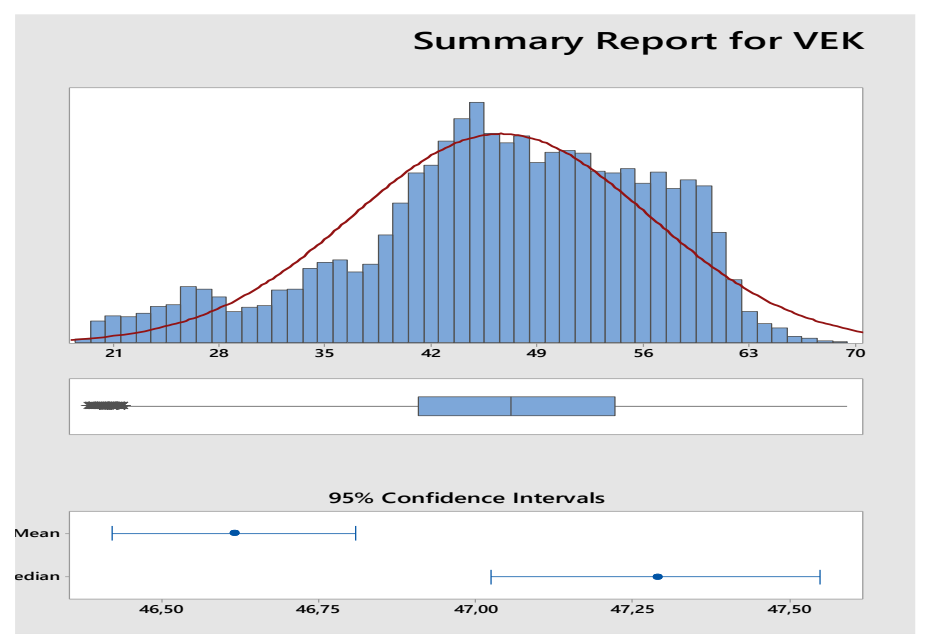

Figure 1

Characteristics of the sample structure

Concerning the distribution of the sample of respondents by age and gender, the average age of women is slightly higher than that of men. The difference between the first quartile is smaller in Figure 2.

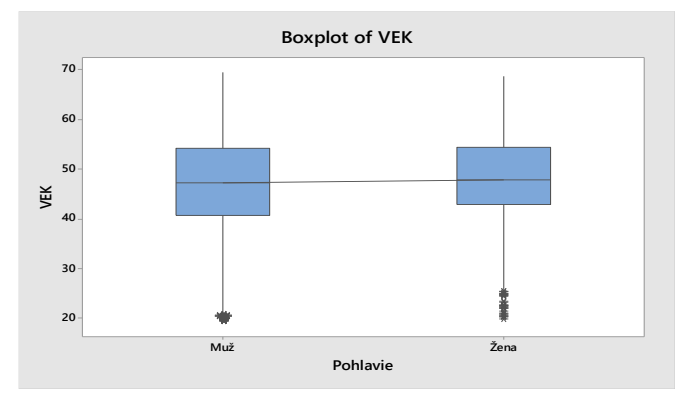

Figure 2

Age structure by gender

Within the analysis, we worked with two samples: family and non-family employees, women, and men. The variables we followed were age, education, and the involvement of entrepreneurship within a family business. By correlating age, the line of engagement, and education, we came to the conclusion that the younger generation of family employees had a higher incentive to do business in international markets, and this sample was also milder in identifying barriers to doing business. In the case of non-family employees in the companies we 
surveyed, the high dependency was found - the higher the level of education the respondents had, the lower were the barriers to international business. The most important motives of an entrepreneur to do business abroad was the lack of room for development in the home country followed by a wish to have higher sales.

In our research, we set out a few hypotheses that we verified. The student's t-test was used to verify them. The results were determined at the significance level of $\alpha$ $=0.05$. The T-test was chosen based on the Fisher F-test result where the p-value was $\mathrm{P}>0.05$. By calculating the Student's $t$ and comparing with the critical value, we came to the conclusion.

Hypothesis H1: "There is a statistically significant difference in the experience of working abroad between family and non-family employees."

There is no significant difference in experience from abroad. We were unable to confirm this hypothesis.

Table 1

Results of the T-test

\begin{tabular}{|l|l|l|}
\hline T-test & $\mathrm{t}$ Stat & $\mathrm{t}$ crit (2) \\
\hline T-test values & & \\
\hline & 0.558463 & 2.014103 \\
\hline
\end{tabular}

On this partial issue, we assumed that the work experience from abroad could help the Slovak family businesses. Experience from abroad, from a developed market economy, could contribute more effectively to the development of Slovak family businesses. This fact was not confirmed within our sample.

Hypothesis H2: "There is a statistically significant difference between family and non-family employees in that the family members are in the management of the enterprise."

There is a significant difference between the monitored groups and family members indeed showed significantly more managerial activities within the company. The hypothesis $\mathrm{H} 2$ was confirmed.

Table 2

Results of the T-test

\begin{tabular}{|l|l|l|}
\hline \multicolumn{3}{|c|}{ T-test } \\
T-test values & t Stat & t crit (2) \\
\hline & 2.2907 & 2.0141 \\
\hline
\end{tabular}


Hypothesis H3: "There is a statistically significant difference between family and non-family employees in the areas of management that led to the biggest business development."

There is no significant difference between the variables in the identification of management areas that led to business development. Hypothesis H3 was not confirmed. On this sub-issue, we assumed that family members would approach managerial methods in different ways and practices. However, no significant difference was found within the areas of management that led to business development. We see the reason for this in several possible causes, such as the lack of gradual training, the lack of managerial experience of establishing the practice under specific conditions, the inability to exercise freely its managerial decision, etc. We have identified these reasons in the feedback of respondents.

Table 4

Results of the T-test

\begin{tabular}{|l|c|c|}
\hline \multicolumn{3}{|c|}{ T-test } \\
\hline T-test values & t Stat & t crit (2) \\
\hline & 1.5483 & 2.0141 \\
\hline
\end{tabular}

The barriers to entry international markets were identified as financial demands, absence of a foreign partner, ignorance of the market, fear of an unfamiliar environment, and legislation. Further in our research, we focused on the innovation factors within the family business.

Among the innovation factors, we have included - product quality and services, customer relationship management, customer requirements, proactive approaches in marketing and employee qualification. We performed two regression models of multiple variables using R. Model 1 is shown in the following table.

Table 5

Model 1 Results

\begin{tabular}{|l|l|l|l|l|l|}
\hline & Coefficient & Std. Error & t-ratio & $p$-value & \\
\hline const & 2,06621 & 0,0294836 & 70,08 & $<0,0001$ & $* * *$ \\
\hline $\begin{array}{l}\text { Quality of products } \\
\text { and services }\end{array}$ & 0,0527984 & 0,0153012 & 3,451 & 0,0006 & $* * *$ \\
\hline CRM & $-0,131434$ & 0,0221885 & $-5,924$ & $<0,0001$ & $* * *$ \\
\hline $\begin{array}{l}\text { Customer } \\
\text { requirements }\end{array}$ & 0,0154481 & 0,000556426 & 27,76 & $<0,0001$ & $* * *$ \\
\hline $\begin{array}{l}\text { Proactive marketing } \\
\text { approaches }\end{array}$ & $-0,0360616$ & 0,00124336 & $-29,00$ & $<0,0001$ & $* * *$ \\
\hline $\begin{array}{l}\text { Qualification } \\
\text { employees }\end{array}$ & $-0,00194741$ & 0,000973602 & $-2,000$ & 0,0455 & $* *$ \\
\hline
\end{tabular}




$\begin{array}{llll}\text { Mean dependent var } & 3,334289 & \text { S.D. dependent var } & 0,627007 \\ \text { Sum squared resid } & 2850,956 & \text { S.E. of regression } & 0,537040\end{array}$

The above-mentioned linear regression model constructed by the OLS method explains $26 \%$ of the variability of the dependent variable. The problem, however, is that the p-values for residual normality, heteroscedasticity and multicolinearity were less than 0.001 , implying the rejection of the null hypotheses and thus the model assumptions were not met. For this reason, we made a correction of the heteroscedasticity model, which provided a more credible model without the presence of heteroscedasticity, multicolinearity and residual abnormality. The results are shown in the following table.

Table 6

Model 2 results

\begin{tabular}{|l|l|l|l|l|l|}
\hline & Coefficient & Std. Error & $t$-ratio & $p$-value & \\
\hline const & 2,72620 & 0,0332163 & 82,07 & $<0,0001$ & $* * *$ \\
\hline $\begin{array}{l}\text { Quality of products } \\
\text { and services }\end{array}$ & 0,0452121 & 0,0135721 & 3,331 & 0,0009 & $* * *$ \\
\hline CRM & $-0,179499$ & 0,0190910 & $-9,402$ & $<0,0001$ & $* * *$ \\
\hline $\begin{array}{l}\text { Customer } \\
\text { requirements }\end{array}$ & 0,00731404 & 0,000569556 & 12,84 & $<0,0001$ & $* * *$ \\
\hline $\begin{array}{l}\text { Qualification of } \\
\text { employees }\end{array}$ & $-0,0411669$ & 0,00102319 & $-40,23$ & $<0,0001$ & $* * *$ \\
\hline $\begin{array}{l}\text { Proactive marketing } \\
\text { approaches }\end{array}$ & $-0,00012038$ & 0,000799010 & $-0,1507$ & 0,8802 & \\
\hline
\end{tabular}

Statistics based on the weighted data:

\begin{tabular}{|c|c|c|c|}
\hline Sum squared resid & 33935,73 & S.E. of regression & 1,852850 \\
\hline R-squared & 0,214326 & Adjusted R-squared & 0,213691 \\
\hline
\end{tabular}

Statistics based on the original data:

\begin{tabular}{|l|l|l|l|l|}
\hline Mean dependent var & 3,334289 & & S.D. dependent var & 0,627007 \\
\hline Sum squared resid & 3020,611 & & S.E. of regression & 0,552789 \\
\hline
\end{tabular}

Since this model meets the prerequisites for OLS models and its overall p-value is less than the significance level, we reject the hypothesis that the model could be zero. Thus, it is statistically significant. The only statistically insignificant variable was proactive marketing approaches. For completeness, below is the picture for the Q-Q fence. 


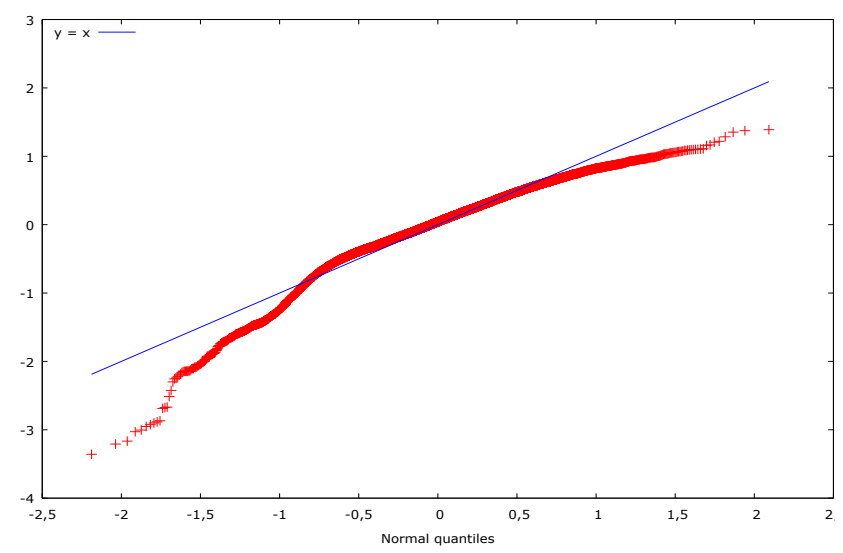

Figure 3

Q-Q plot for model 2

These results show that it is very important to apply strategic management decisions to a family business at the international level and that the elements of internationalization need to be maintained chronologically in order to be successful in foreign markets. The entrepreneur's priority is to place emphasis on the quality of the products produced, the quality of the services provided, the cultivation of fair customer relations, and the fulfillment of customer requirements.

\section{Conclusions}

Entrepreneurship is a priority for the market economy in terms of its functioning. The core of entrepreneurship in the business sector, which consists of business units. The vast majority of businesses are small and middle-sized enterprises, and in this group, a special form of business - a family business can be found. Family businesses are an important part of the economy not only of the European Union but also of Slovakia. They show a greater ability to create new jobs, which are related to their high sense of responsibility, tend to introduce new solutions for practice, bring innovative products and offer innovative services, provide personal input into mutual business relationships. These non-gas businesses are not typical. On the other hand, they also struggle with many, often specific problems.

This article discusses the important characteristics of family businesses, pointing out the burning issues that family business management has to address. In a sample of 185 family businesses, we analyzed several factors that we defined as significant. In particular, developmental and developmental factors hampering factors. We evaluated information from business units using quantitative methods. The results were presented numerically and graphically. In conclusion, we would like to point out important facts resulting from a well-known survey: the experience gained abroad does not contribute significantly to the development of 
Slovak family businesses. Further in our research, we focused on the innovation factor within the family business, these factors were identified as quality of products and services, customer relationship management, customer requirements, proactive approaches in marketing and employee qualification. We constructed two regression models for multiple variables using the $\mathrm{R}$ program. Considering the outcome of the first model, we had to correct it for heteroscedasticity, which provided a more credible model without the presence of heteroscedasticity, multicollinearity, and residue abnormality. Since this model meets the prerequisites for OLS models and its overall p-value is less than the significance level, we reject the hypothesis that the model could be zero. Thus, it is statistically significant. The only statistically insignificant variable was only proactive marketing approaches.

\section{Acknowledgement}

This paper is part of the research carried out within the project VEGA 1/0813/19 Management of the development of innovative and start-up forms of business in the international business environment and verification of the INMARK concept.

\section{References}

[1] I. Ahmad, J. Olah, J. Popp, and D. Mate: Does Business Group Affiliation Matter for Superior Performance? Evidence from Pakistan, Sustainability, Vol. 10, issue 9, Article Nr. 3060, 2018, doi: 10.3390/su1009306

[2] C. De Alwis: Owner family and business succession in family owned companies, Acta Oeconomica Universitatis Selye, Vol. 5, issue 1, 2016, pp. $40-54$

[3] A. Androniceanu, M. Comănescu and D. Jiroveanu: Factors with major influence on disparities across regions and their impact on economic development in Romania, Proceedings of the $29^{\text {th }}$ International Business Information Management Association Conference - Education Excellence and Innovation Management through ision 2020: From Regional Development Sustainability to Global Economic Growth, Vienna, 2017, pp. 1743-1753

[4] C. Anyakoha: Job analysis as a tool for improved organizational performance of SMEs in Lagos, Nigeria, Central European Journal of Labour Law and Personnel Management, Vol. 2, issue 1, 2019, pp. 7-16, doi: 10.33382/cejllpm.2019.02.01

[5] C. Anyakoha: Strategic management practise and micro-small enterprises financial performance in Imo, South Eat Nigeria, Acta Oeconomica Universitatis Selye, Vol. 8, issue 1, 2019, pp. 41-52

[6] Z. Bayar, R. Remeikiene, A. Androniceanu, L. Gaspareniene and R. Jucevicius: The Shadow Economy, Human Development and Foreign Direct Investment Inflows, Journal of Competitiveness, Vol. 12, issue 1, 2020, pp. 5-21, doi:10.7441/joc.2020.01.01 
[7] J. Belas, B. Gavurova and P. Toth: Impact of selected charakteristics of SMEs on the capital structure, Journal of Business Economics and Management, Vol. 19, issue 4, 2018, pp. 592-608

[8] J. Belas, E. Ivanova, Z. Rozsa and J. Schonfeld: Innovations in SME segment: importat factors and differences in the approach by size and age of the company, Transformations in Business and \& Economics, Vol. 17, issue 3, 2018, pp. 55-71

[9] J. Belas, I. Kmecová and M. Cepel: Availability of human capital and the development of the public infrastructure in the context of business activities of SMEs, Administratie si Management Public, Vol. 2020, issue 34, 2020, pp. 27-44, doi: 10.24818/amp/2020.34-02

[10] M. Bure and R. K. Tengeh: Implementation of internal controls and the sustainability of SMEs in Harare in Zimbabwe, Entrepreneurship and Sustainability Issues, Vol. 7 issue 1, 2019, pp. 201-218

[11] G. Çera, M. Meço, E. Çera and S. Maloku: The effect of institutional constraints and business network on trust in government: an institutional perspective, Administratie si Management Public, Vol. 2019, issue 33, 2019, pp. 6-19, doi: 10.24818/amp/2019.33-01

[12] Z. Dudic, B. Dudic, M. Gregus, D. Novackova and I. Djakovic: The Innovativeness and Usage of the Balanced Scorecard Model in SMEs, Sustainability, Vol. 12, issue 8, Article Number 3221, 2020, doi: $10.3390 / \mathrm{su} 12083221$

[13] B. Dudic, Z. Dudic, J. Smolen and V. Mirkovic: Support for foreign direct investment inflows in Serbia, Economic Annals-XXI, Vol. 169, issue 1-2, 2018, pp. 4-11, doi:10.21003/ea.V169-01

[14] E. Dulová Spisakova, L. Mura, B. Gontkovicova and Z. Hajduova: R\&D in the context of Europe 2020 in selected countries. Economic Computation and Economic Cybernetics Studies and Research, Vol. 51, issue 4, 2017 pp. 243-261

[15] K. Haviernikova, V. Snieska, V. Navickas and D. Burksaitiene: The attitudes of small and medium entrepreneurs toward cluster cooperation: the expectations and reality, Transformations in Business \& Economics, Vol. 18, issue 3, 2019, pp. 191-205

[16] D. Halasi, P. Schwarcz, L. Mura and O. Rohacikova: The impact of EU support resources on business success of family-owned businesses, Potravinarstvo Slovak Journal of Food Sciences, Vol. 13, issue 1, 2019, pp. 191-205, doi:10.5219/1167

[17] J. Horecký and M. Blažek: Dependent work and internship, Central European Journal of Labour Law and Personnel Management, Vol. 2, issue 2, 2019, pp. 7-20, doi:10.33382/cejllpm.2019.03.01 
[18] E. Ivanova: Barriers to the development of SMEs in the Slovak Republic, Oeconomia Copernicana, Vol. 8, issue 2, 2018, pp. 255-272

[19] N. Kachanek, G. Stalk and A. Bloch: What you can learn from family business, Harward Budiness Review, Boston, 2012

[20] A. Kljucnikov, L. Mura and D. Sklenar: Information security management in SMEs: factors of success, Entrepreneurship and Sustainability, Vol. 6, issue 4, 2019, pp. 2081-2094

[21] L. Kvašňák and X. Makarovičová: How to save a family business, Weekly TREND, online, cit. Oct. 2019, Analaible at: https://www.etrend.sk/trendarchiv/rok-2018/cislo-35/ako-zachranit-rodinne-firmy.html

[22] J. Lazikova, A. Bandlerova, O. Rohacikova and P. Schwarcz: Regional Disparities of Small and Medium Enterprises in Slovakia, Acta Polytechnica Hungarica, Vol. 15, issue 8, 2018, pp. 227-246

[23] M. Mészáros and K. Divékyová: Immediate termination of employment relationship by the employer, Central European Journal of Labour Law and Personnel Management, Vol. 2, issue 2, 2019, pp. 33-43, doi: 10.33382/cejllpm.2019.03.03

[24] L. Mura: Entrepreneurship internationalization - Case of Slovak family businesses, AD ALTA-Journal of Interdisciplinary Research, Vol. 9, issue 1, 2019, pp. 222-226

[25] L. Mura, and P. Kajzar: Small Businesses in Cultural Tourism in a Central European Country, Journal of Tourism and Services, Vol. 10, issue 19, 2019, pp. 40-54, doi:10.29036/jots.v10i19.110

[26] B. Mucha: Tools to increase the effectiveness of comprehensive management of emergencies affected by climate change in the Slovak republic, Proceedings of International Multidisciplinary Scientific GeoConference Surveying Geology and Mining Ecology Management, SGEM, Vol. 19, issue 5.4, 2019, pp. 573-580, doi: $10.5593 /$ sgem $2019 / 5.4 / \mathrm{S} 23.075$

[27] J. Nagy, J. Olah, E. Erdei, D. Mate and J. Popp: The Role and Impact of Industry 4.0 and the Internet of Things on the Business Strategy of the Value Chain - The Case of Hungary, Sustainability, Vol. 10, issue 10, Article Nr. 3491, 2018, doi:10.3390/su10103491

[28] A. Rahman, MT. Rahman and J. Belas: Determinants of SME Finance: Evidence from Three Central European Countries, Review of Economic Perspectives, Vol. 17, issue 3, 2017, pp. 263-285

[29] E. Rogalska: Multiple-criteria analysis of regional entrepreneurship conditions in Poland, Equilibrium - Quarterly Journal of Economics and Economic Policy, Vol. 13, issue 4, pp. 707-723, 2018, doi: 10.24136/eq.2018.034 
[30] N. Selivanova-Fyodorova, V. Komarova, J. Lonska and I. Mietule: Differentiation of internal regions in the EU countries, Insights into Regional Development, Vol. 1, issue 4, 2019, pp. 370-384

[31] P. Serina: Family business in Slovakia, online, cit. 08. 10. 2019, Bratislava March 2011, avalaible at: http://www.sbagency.sk/sites/default/files/ file/studia_rodinne_podnikanie_na_slovensku.pdf

[32] R. Suliková and N. Meyer: Motivating by flexibility: which role plays the company's culture, Proceedings of the Managing global diversities Conference, 2018, pp. 41-50

[33] B. Ślusarczyk and B. Ul Haque: Public services for business environment: challenges for implementing Industry 4.0 in Polish and Canadian logistic enterprises, Administratie si Management Public, Vol. 2019, issue 33, 2019, pp. 57-76, doi:10.24818/amp/2019.33-04

[34] J. Šétafy: Family business needs a new modern definition also in Slovakia, online, cited 15. 11. 2019, Bratislava May 2014, avalaible at: https://www.sfa.sk/sk/novinky/detail/rodinne-podnikanie-potrebuje-aj-naslovensku-novu-modernu-definiciu

[35] M. Svec, A. Madlenak and J. Horecky: GDPR and its impact on the direct marketing management, Proceedings of $15^{\text {th }}$ Annual International Scientific Conference on Marketing Identity - Digital Mirrors Location, Book Series: Marketing Identity, 2018, pp. 344-353

[36] M. Švec and A. Madleňák: Legal frameworks for the phygital concept, European Journal of Science and Theology, Vol. 13, issue 6, 2017, pp. 209217

[37] R. Zajkowski and A. Domańska: Differences in perception of regional proentrepreneurial policy: does obtaining support change a prospect?, Oeconomia Copernicana, Vol. 10, issue 2, 2019, pp. 359-384

[38] J. Zygmunt: Entrepreneurial activity drivers in the transition economies. Evidence from the Visegrad countries, Equilibrium - Quarterly Journal of Economics and Economic Policy, Vol. 13, issue 1, 2018, pp. 89-103

[39] J. Žufan, M. Civelek, I. Hamarneh and L. Kmeco: The Impacts of Firm Characteristics on Social Media Usage Of SMEs: Evidence from the Czech Republic, International Journal of Entrepreneurial Knowledge, Vol. 8, issue 1, 2020, pp. 102-113, doi:10.37335/ijek.v8i1.111 